\title{
ISLAM POST 911: INDONESIAN EXPERIENCE
}

\author{
By: Juhaya S. Praja*
}

Abstrak

Walaupun peristiwa teror 911 terjadi di Amerika, namun implikasinya meluas ke selurub dunia. Hal ini dapat dipahami dari kebijakan Amerika tentang terorisme yang berpengarub langsung maupun tidak langsung terbadap semua negara di dunia, termasuk, Indonesia. Indonesia sebagai negara berpenduduk muslim terbesar di dunia memiliki kepentingan yang luar biasa untuk sesegera mungkin merespon isu global dengan cepat. Respon tersebut diantaranya dengan membuat perangkat bukum, baik berupa undang-undang maupun peraturan presiden. Apalagi Indonesia diduga menjadi sarang teroris yang indikasinya dapat dilibat dari beberapa tokob yang terkait dengan jaringan al-Qaeda. Selain dengan perangkat bukum, Indonesia juga perlu melakukan pendekatan agama dan budaya. Pendekatan agama misalnya, tafsir jihad perlu terus diwuacanakan agar lebib dekat dengan pembelaan terhadap nilai-nilai kemanusiaan melalui reformasi kurikulum semua jenjang pendidikan Islam.

كان المجوم الموجهية اللى مركز التجاري الغالمي المعروف باسم WTC له أثر كبير وتتوسع إلى دول

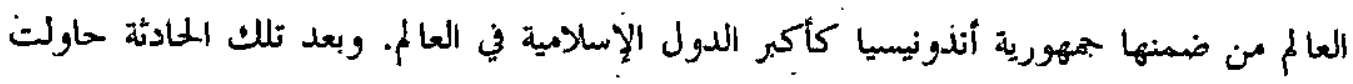
هكومة مذا البلد إلل وضع القانون والنظم المتضدة لعملية الإزهاب. ولأن الغرب اقمى إندونيسيا كمركز للإرهاب وتشير. هذا وجود العلاقة بين رجال الدين بتنظيم "القاعدة" المنسوبة.إلى ابن لادن.

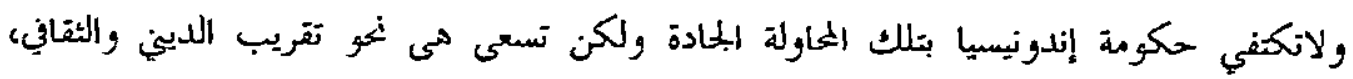
كموسيع معني البهاد الذي يشمل الدفاع للقيم الإسلامية المهمودة و تغيير المواد التربية.

Keywords: terorisme, bukum dan jïhad

* Visiting Expert of UNAFEI Fu Chu, Tokyo, Japan. Chairperson; Ph.D Program of Islamic Law Islamic State University of Bandung; Rector, Latifah Mubarokigah Institute for Islamic Studies, Pondok Pesantren Suryalaya, Tasikmalaya, West Java Indonesia. 


\section{A. Introduction}

As the world's fourth largest country and the most populous Muslim nation on earth, Indonesia hosts an array Muslims groups ranging from traditional Islam to highly liberal. The vast majority of Indonesian Muslims are moderate and toletant, but several radical groups have emerged. The assumption of emerging Indonesian Muslims extremist mote cleatly when al-Qaeda was introduced to this region by Abdullah Sungkar. 'The first indications of al-Qaeda's plan to infiltrate Indonesia became known to Indonesian intelligence in 1998, a few month before Sungkat left Malaysia and returned to Indonesia. Letters sent by those who prominent Islamic figures in Indonesia were intercepted. They contained a message from Osama bin Laden: "that the most important obligation for Muslims nowadays was to work hatd in order to free Arabian lands from the guip of enemy of Allah, specially pointing to American Christian and Jews". Reflecting their relationship to the al-Qaeda leader, Sungkar also stated in the letter that "they were willing to show the most secure way to visit Osama whenever the Islamic prominent figures would like to do so". In response, al-Qaeda dispatched a high-powered delegation to the region to enhance ideological influence and operational commitment. Foreign intelligence agencies reported that Ayman al-Zawahiri and Muhammad Atef visited Moluccas and Irian Jaya in 2000 , both area affected by long-running conflict, thus conforming with alQaeda's preference for regtouping in areas where the rule of law is weak. ${ }^{2}$ Many operations conducted by al-Qaeda in Indonesia, the millennium bombings on Christmas Eve 2000 are very instructive of their tactic, The campaign of bombings against thirty churches in Jakarta, West Java, North Sumatera, Riau, Bandung, East Java and West Nusa Tenggara was coordinated with al-Qaeda, Manila Attacks and investigation revealed they were authorized from Malaysia and Afganistan. ${ }^{3}$

It was no doubt that the tragic events of 911 acted by al-Qaeda's network. The 19 terrorists were identified as Múslims and they have generated set American Muslims back. America before 911 was on the verge of accepting Islam as one of it own, but after the attack of 911 it has paused to once again reassess Islam and Muslims. ${ }^{4}$ Americans were crying out in anguish: "Why do they hate us"? The question was echoed through out Europe, since no doubted that the attack was directed not just at America, but at the whole of Western civilization. ${ }^{5}$ What happened on

' Rohan Gunaratna (2002), Inside al-Qaeda Global Netwowrk Terror, New Yotk-London-TorontoAuckland, pp. 198-200.

${ }^{2} I b i d$.

${ }^{3}$ Ibid.

${ }^{+}$M.A. Muqqtadir Khan (2002), American Muslims, Bridging Faith and Freedom, Amana Publication, p. 2.

${ }^{5}$ Robert Van de Weyer (2001), Islam and the West. A New Polticaland Religious Order post September 11, Kuala Lumpur: Books, p. ix. 
911 and afterwatd has had significant and mostly negative consequences for the Muslim communities in Europe, and has set back the process of mutual accommodation between Muslims and European populations and the integration of both Islam and Muslims into Europe's social, cultural and political landscape. ${ }^{6}$ In the aftermath of 911, people of goodwill on both side of the divide between the JudeoChristian and Muslim worlds were filled with deep anxieties. For Westerners, it seemed that a dreadful clash of civilizations had become imminent and unavoidable. For Muslims, it was clear that serious injury had been done to the most powerful nation on earth - a wound that could only call for the terrible retaliation. Many Jew and Christians seized on the belief that something feral and evil in the faith of Muhammad had made 911 inevitable. Many Muslims feared that a new "crusade" against Islam would ensue, expressing deeply ingrained impulses in the West. ${ }^{7}$

Fortunately, on September 17, 2001, President George W. Bush stood in the Islamic Center of Washington DC, the capital's most important mosque. Following the honor six days before, he sought to calm the fears of Americans about terrorism. "The face of terror is not the true face of Islam", he said "Acts of violence against innocents violate the fundamental tenets of the Islamic faith and it's important for my fellow Americans to understand that". ${ }^{8}$

In the light of the Tragedy 911, Indonesia's mainstream Islamic groups, Muhammadiyyah and Nahdlatul Ulama immediately denounced the bombing as cruel and uncivilized crime against humanity. Further they stated that the recurrence of such cruel and uncivilized action depict the need to further strengthen the capacity of the security officials to disclose the terrorist's network of theit efforts in combating tertorism in Indonesia.

\section{B. Indonesian's Criminal Policy on Terrorism}

One year after 911 tragedy, Indonesia challenged by Bali Suicide Bombing I of October 12, 2003, JW Marriott Hotel Bombing of August 5, 2005, Bali Suicide Bombing II of October 1, 2005. Indonesian government tesponses these terrorist challenges within the difficult economic environment. The choice to actively join ot not join in the fight against terrorism carried weight economic consequences. The decision to respond positively, if tentatively first, to the call to combat global terrorism was welcomed by the U.S. and, generally by the international community.

'Shireen T. Hunter (ed) (2002), Islan Europe's Second Religion, Published in cooperation with the Center for Strategic and International Studies Washington DC., by Praeneger, Westport, ConnecticutLondong, p. 277.

${ }^{7}$ Steephen Schwartz (2002), The Two Faces of Islam: The House of Sa'ud from Tradition to Terror, New York: Doubleday, p. xi.

${ }^{8}$ Ibid, p. 226. 
The following highlights Administration of Indonesian's efforts so far to have created the foundation on which Indonesia continue to build the strength and capacity to counter tertorism. Efforts of the Indonesian's government to counter terrorism, in preventive and post-attack measures, have been carried out in four fronts: 1. National: institutional capacity building and strengthening legal infrastructure;

2. Bilateral: establishing bilateral mechanism for cooperation and securing bilateral assistance for institutional capacity building;

3. Regional: enhancing regional cooperation among ASEAN member countries, promoting extra-regional cooperation;

4. International: strengthening the United National multilateral diplomacy.

Indonesia recognizes the urgent need to mount a universal and concerted response to rid societies of the urgent of criminal acts of terrorism. Indonesia adopted Law No.15/2003 and 16/2003 as needs arise to crack down on terrorism following the terrorist bombing attack in Bali on 12 October 2002. The first law serves as the general guideline for combating terrorists. The second law is specially drawn up to deal with the terrorist attacks against tourists in Bali on 12 October 2002, which left nearly 200 dead. It stipulates the law enforcers' powers to investigate and prosecute the perpetrators of the attack.

Two Presidential Instructions were also issued in the aftermath of the Bali Tragedy, namely Presidential Instruction No. 4/2002 instructing the Coordinating Minister for Political and Security affairs to formulate a comprehensive policy in combating terrorism, and Presidential Instruction No. 5/2002 instructing the Head of the National Intelligence Agency to coordinate the activities of all the other intelligence agencies. As a follow up to Presidential Instruction No. 4/2002, the Desk for Coordination of Eradicating Terrorism (DCET) was established within the Office of the Coordinating Minister for Political and Security Affairs. The Desk, composed of representatives from the relevant governmental agencies, is tasked to formulate Government policies in combating and eradicating terrorism in a coordinated manner.

The Law $16 / 2003$ is drawn up to allow for the principle of retroactivity to be applied in the case of 12 October 2002 terrorist attacks. Opposition to this principle of retroactivity maintains that it goes against both general legal principles and the 1945 Constitution. Citics also fear of human rights violations resulting from the enforcement of such principle. However, terrorist attacks are not ordinary crimes. Terrorism has an indiscriminate, non-selective or random target. Terrorist attacks are extraordinary crimes having intended to create a state of tertor. Such crimes demand an extraordinary tesponse. Nevertheless, the principle of retroactivity will strictly apply only for the purposes of investigation and prosecution against the perpetrators of 12 October 2002 terrorist attacks. 
The legislation on terrorism provides a death penalty for natural person and a one trillion Rupiah maximum fine for a corporation convicted of committing or threatening to commit acts of terrotism. It allows the authorities to detain people for seven days in the absence of strong legal evidence that the person may have committed terrorist acts. Intelligence reports could be used as prima facie evidence after being approved by a court of law with the approval process taking no longer than three days.

For investigation purposes, a suspect may be detained for six months. In implementing these regulations on terrorism, the government will do its utmost to avoid excesses for a better cause, which is to prevent violations of human rights and to protect its citizens from threat to their safety and security.

Following the 5 August 2003 bomb blast in Jakarta, the government of Indonesia revised the Law no.15/2003 with a view to ensuring its effectiveness in efforts to eliminate the criminal acts of terrorism.

It is widely identified that tertorism activities may be funded from by the other kind of crime, such as money laundering. Pursuant to Law No. 15/2002 pertaining to Crime on Money Laundering, the government of Indonesia has also established an independent financial intelligence unit, the Indonesia Financial Transaction Report and Analysis Center (INTRAC), the main task of which is to prevent and eradicate the crime of money laundering.

The Indonesian legislation on combating criminal acts of terrorism is a specific one, as it contains new provisions that are not found in prevailing legislation, and are deviating from the general provision of Criminal Code and the Criminal Procedural Code.

This legislation also specifically contains the provision on the scope of international and transnational jurisdiction and special provisions on criminal acts of terrorism that relate to international terrorism activities. These special provisions are not discriminative in nature. Instead, they are the government's commitment to exercise Article 3 of the Convention against Terrorist bombing (1997) and the Convention on the Suppression of Financing Terrorism (1999).

More detailed specifications of this legislation as follows:

1. The umbrella for other legislation relating to the elimination of criminal acts of terrotism;

2. This legislation is strengthened by criminal sanctions and simultaneously a coordinating act that strengthens the provisions of other legislation; and

3. Special provisions on the protection of the tights of the suspects or defendants, referred to as the "safeguarding rules". The provisions introduce among others a new legal institution in the criminal procedural code referred to as 'heating' that functions as an institution for 'legal audit' to all intelligence reports and docu- 
ments submitted by the investigators to determine whether or no to proceed with the investigation on alleged acts of terrorism;

4. Affirming that criminal acts of terrorism are neither political crimes nor politically motivated crimes nor crimes with political objectives. Therefore, the elimination there of within the bilateral and multilateral cooperation may be implemented more effectively;

5. Contains provisions that enable the President to establish a special ad boc institution on the advice of the National Police Cbief. The existence of the force is based on the principles of transparency and public accountability (sunshine principle) and/ot the ptinciple of effective time limit (sunset principle) so as to avoid abuse of power by the institution;

6. Contains provisions on jurisdiction based on the territorial, extra-territorial and nationalactive principles, thus it is expected that this legislation can effectively reach criminal acts of terrorism as stipulated in this legislation beyond the national territorial boundaries of the Republic of Indonesia. In order to strengthen the jurisdiction, this legislation also contains the provisions on international cooperation;

7. Contains provisions on the financing of terrorist activities as criminal acts of terrorism, simultaneously strengthening the law on Criminal Acts of Money Laundering:

8. The provisions of legislation do not apply to the freedom of expression before the public through demonstrations, protests or other activities of advocacy. If in the freedom of expression there are acts with criminal elements, the Criminal Code and the Criminal procedural Law shall apply;

9. Maintaining the application of special minimum ctiminal sanctions to discourage and deter the perpetrators of criminal acts of terrorism.

\section{Counter Terrorism: Cultural and Religious Approach}

Elimination of criminal acts of terrorism in Indonesia is not only a question of law and law enforcement but also a social, cultural, economic and religious issues that closely-related to the security of the nation. Therefore, the policies and measures to prevent and eliminate it should also be aimed at maintaining the equilibrium in the obligation to protect the state's sovereignty, the human rights of the victims, the witnesses and the suspects or defendants.

The unprecedented of 911 in the U.S. have had a strong negative impact on culture, politic, economic and belief of Indonesian Muslims as a whole. This negative impact become more seriously after the Bali Tragedy on 12 October 2002 which appeared to be the second largest loss of life after 911 (killed over 200 and wounded few hundreds); again a shocking tragedy took place at the JW.Marriott Hotel Jakarta on August 5, 2003 and Bali II, October 1, 2005. Buyers of Indonesian products have reportedly been unwilling to travel to Indonesia and have begun to source 
purchases elsewhere in the tegion. In part, this is a result of the perception that foreigners, particularly Americans, may be targets of extremists and the issuance of threats against American interests has reinforced this negative image of Indonesia. Indirect evidence of the negative impact of the September 11 attacks is seen in the fact that growth rates of US imports of nine of the ten top labor-intensive product groups from Indonesia were negative in the fourth quarter 2001. In seven of nine cases, growth became negative, or if already negative, worsened in the fourth quarter compared with the third quarter of the year. These products include apparel items (5 SITC 3-digit product groups) footwear, and toys and sporting goods. The downside of the tetrorist attacks of September 11 are likely to be magnified should Indonesia be unable to respond effectively to reverse these negative perceptions in the US. ${ }^{9}$

The defendant of suicide bombing Bali I, Amrozi described his Islamic opinions to his family and covered by local daily news paper Pikiran Rakyat in regard the holyday of Islam, Idul Fitri $1426 \mathrm{H}$ in his Jail at Nusakambangan. He stated that he is the Islamic martyr and to be proud to be sentenced by death. He believes that he will be in heaven as the God's reward upon his act of terrorism which he regarded the Jihad in accordance with Quran's command. Undoubtedly that such an opinion is really wrong and depicts a little knowing of Islamic doctrine, but distorting and hijacking the meaning of jihad. Therefore, eliminating such act of terrorism based on the light understanding of Islamic doctrine, especially on the meaning of jihad, must be a priority action of the government. Meanwhile the late suspected suicide bombers of Bali II (R. Aja's Café Kuta Bali), Aip Hidayat, Misno and Salik Firdaus come from poor family and they have a little knowledge on Islam that make them easily to be influenced by misused concept of jihad and Islam. This is to say that economic factor and the lack of knowledge on the true meaning of jithad play the role to trigger someone to involve in the act of terrotism. Therefore, dissemination the true meaning of jihad and the danger of misused its concept is extremely needed as a way to eliminate terrorism among the Muslims.

Eliminating terrorism within Muslims society considering religious approach highly suggested to disseminate the real meaning of jihbad and "sword verses" and the abused ones as well. Short description on the meaning of true and abused Islamic jïhâd may be summarized as follows: The two broad meaning of jibâd, nonviolent and violent, are contrasted in a well-known Prophetic tradition. It's said that when Muhammad returned from battle he holds his followers: "We return from the lesser jïhâd (warfate) to the greater jïbâd". The greater j̈̈bâd is the more difficult and

${ }^{9}$ William E. James, Indonesia's External Trade and Competitiveness: Assessing the Economic Costs of Terror presented at conference on the Economic Cost of Terrorism: Indonesia's Responses, Shangti-La Hotel, Jakarta, 7 May, 2003. 
more important struggle against one's ego, selfness, greed, and evil.

Jihâd is a concept with multiple meanings, used and abused throughout Islamic history. Although jïbâd has always been an important part of the Islamic tradition, in recent years some have maintained that it is a univetsal religious obligation for all true Muslims to join the jihad to promote Islamic teform or tevolution. Some look around them and see a world dominated by corrupt authoritarian regimes and a wealthy elite minority concerned solely with its own economic prosperity and awash in Western culture and values. Western governments ate petceived as ptopping up oppressive regimes and exploiting the region's human and natural resources, robbing Muslims of their culture and theit option to be governed according to their own choice and to live in a mote just society.

The defensive nature of jibad is cleatly emphasized in QS. 2:190, "And fight in the way of God with those who fight you, but agrees not: God loves not the aggressors". The Quran provided detailed guidelines and regulations regarding the conduct of war: who is to fight and who is exempted (QS. 48:17, 9:91), when hostiles must cease (QS. 2:192) and how prisoners should be treated (QS. 47:4). Most important verses such as QS. $2: 294$ emphasized that warfare and the response to violence and aggression must be proportional: "Whoever transgresses against you, respond in kind".

However, Quranic verses also underscore that peace, not violence and watfare, is the norm. Permission to fight the enemy balanced by a strong mandated for making peace; "If your enemy inclines toward peace, then you too should seek peace and put your trust in God" (QS. 8:61) and "Had Allah wished, be would bave made them dominate you, and so if they leave you alone and do not fight you and offer you peace, then Allab allows you no way against them" (QS. 4:90). From the earliest time, it was forbidden in Islam to kill noncombatants as well as women and children and monks and rabbis, who were given the promise of immunity unless they took part in fighting.

But what of those verses, sometimes referred to as the "sword verses" that call for killing unbelievers, such as, "When the sacred motbs have passed, slay the idolaters wherever you find them, and lie in wait for them, at every place of ambush" (Q 9:5). These same verses have also been selectively used or abused by religious extremist to develop a theology of hate and intolerance and to legitimate unconditional warfare against unbelievers. The Ulama (religious scholar) said that "sword verses" abrogated or overrode the eatlier Quranic verses that limited jihad to defensive war: in fact, however, the full intent of "When the sacred months have passed, slay the idolaters wherever you find them" is missed or distorted when quoted in isolation. For it is followed and qualified by: "But if they repent and fulfill their devotional obligations and pay zakat [charitable tax on Muslims], then let them go their way, for God is forgiving and kind" QS.9:5. The same is true of another often quoted verse: "Fight those who believe not in God nor Last Day, nor bold that forbidden wbich had been forbidden by God and 
His Apostle, nor bold the religion of truth [even if they are] of the People of the Book," which is often cited without the line that follows "Until they pay the tax with willing submission, and feel themselves subdued" QS. 9:29

Terrorists like Osama bin Laden as well as Indonesian terrorists go beyond classical Islam' criteria for a just jïhâd and recognized no limits but their own, employing weapons or means. They reject Islamic law's regulations regarding the goals and legitimate means for a valid jithâd : that violence must be proportional and that the only the necessary amount of force should be used to repel the enemy, that innocent civilians should not be targeted, and that jibatd must be declared by the ruler or head of state. Today, individuals and groups, religions and lay, seize the right to declare and legitimate unholy war of terrorism in the name of Islam.

Although most Indonesians are Sunni and follow their Islamic school of law responses to marginalize extremists and develop a political theory that emphasized stability over chaos and anarchy, but did not dissuade all from extremist path. After 911 and couple years before, extremist groups have arisen up to challenge Indonesian government and terrorized their population and attack foreign interest. As stated by "an Indonesian suspected terrorist" that he is the true believer struggling against a pagan society of unbelief or the acts of idolaters in the country. The tertorists attempt to impose their ideological brand of Islam and "hijacked" Islamic doctrines such as jihad, claiming to be defending true Islam, to legitimate their illegitimate use of violence and acts of terrorism.

\section{Concluding Remarks}

Combating terrorism and securing the nation and the people from future terrorist attacks are the top priority of Indonesian government. Indonesian Muslims denounced the terrorist attacks as cruel and uncivilized crime against humanity. However this most populous Muslim nation on earth, Indonesia hosts an array of Muslim groups ranging from traditionalist to highly liberal. Early combating on terrorism will be more effective through reformation of Islamic curriculum for all level of education endorsed by the government and the 'ulama (Muslim Scholars). 
10 Millab Vol. VI, No. 1, Agustus 2006

\section{BIBLIOGRAPHY}

Hunter, Shireen T. (ed) (2002), Islam Europe's Second Religion, Published in cooperation with the Center for Strategic and International Studies Washington DC., by Praeneger, Westport, Connecticut-London.

James, William E. Indonesia's External Trade and Competitiveness: Assessing the Economic Costs of Terror presented at conference on The Economic Cost of Terrorism: Indonesia's Responses, Shangri-La Hotel, Jakarta, 7 May, 2003.

M.A. Muqtadir Khan (2002), American Muslims, Bridging Faitb and Freedom, Amana Publication.

Rohan Gunatatna (2002), Inside al-Qaeda Global Netwowrk Terror, New York-London-Toronto-Auckland.

Schwartz, Steephen (2002), The Two Faces of Islam: the House of Sa'ud from Tradition to Terror, New York: Doubleday.

Weyer, Robert Van de (2001), Islam and the West: A New Political and Religious Order Post September 11, Kuala Lumpur: Books. 